\title{
Filamentation promotes F'lac loss in Escherichia coli K12
}

\author{
Eugenio A. DebBiA* \\ Institute of Microbiology, University of Genoa, Viale Benedetto XV, 10, 16132 Genova, Italy
}

(Received 14 April 1992; revised 15 June 1992; accepted 25 June 1992)

\begin{abstract}
The stability of plasmid $F^{\prime}$ lac in Escherichia coli strain SP45 (a temperature conditional mutant which grows as spherical cells at $42^{\circ} \mathrm{C}$ and as a rod at $30^{\circ} \mathrm{C}$ ) was studied. $\mathrm{F}^{\prime}$ lac elimination was demonstrated when bacteria exposed to subinhibitory concentrations of various chemicals were induced to form filaments. No plasmid loss was found when spherical cells were subjected to the same treatments. Plasmid loss was also observed in dnaA46 and lex $A 41$ mutants when cell filamentation was induced at $42{ }^{\circ} \mathrm{C}$, but not when they were cultured at $30^{\circ} \mathrm{C}$. Nalidixic acid promoted $\mathrm{F}^{\prime}$ lac elimination at $0.25 \mathrm{~g} \mathrm{ml}^{-1}$ in a $\operatorname{rec} A 13$ mutant and at $1.5 \mu \mathrm{g} \mathrm{ml}^{-1}$ in the rec $A^{+}$counterpart. A marked difference was found in the rate of $F^{\prime} l a c$ elimination from thermosensitive DNA gyrase mutants [gyrA43(Ts) and gyrB41(Ts)] between rods and their spherical (rodA51) derivatives growing at semipermissive temperature $\left(36.5^{\circ} \mathrm{C}\right)$. Plasmids carrying the $c c d$ segment of $F$ in DNA gyrase mutants were lost after 2.5 generations from rods and after 6 generation from spherical cells. Plasmid segregation into non-viable minicell-like elements was found after induction of filaments. These data suggest that plasmid stability is correlated with cell shape and that curing is more easily achieved when bacteria can elongate normally.
\end{abstract}

\section{Introduction}

A large number of chemical and physical agents (curing agents) promote the loss of plasmids from several bacterial hosts (Stanisich, 1988). Studies using DNA gyrase inhibitors have demonstrated the role of this enzyme in plasmid replication and thus in plasmid maintenance (Hooper et al., 1984; Weisser \& Wiedeman, 1985; Michel-Briand et al., 1986). Although these agents have been used to enhance the recovery of plasmid-free derivatives of various bacteria, the precise mechanism of plasmid elimination is not understood.

Novick et al. (1980) demonstrated the loss of high copy number plasmids during protoplast formation and regeneration in Staphylococcus aureus, providing evidence for a relationship between cell envelope and maintenance of plasmids. The first proposal that the bacterial cell envelope is involved in plasmid maintenance came from Jacob et al. (1963) who suggested that plasmids in Escherichia coli are attached to the cell membrane, and that this attachment is necessary for both replication and partition. Indeed, membraneassociated proteins appear to be involved in both plasmid and chromosome partition as reviewed recently by Williams \& Thomas (1992).

\footnotetext{
- Tel. (39) 103537647 ; fax (39) 10516519.
}

In agreement with this interpretation, Rashtchian $e t$ al. (1986) demonstrated that plasmid segregation into minicells depends on the spatial location of these replicons in the host cells and on their association with membrane attachment sites. E. coli minicell mutant strains are characterized by aberrant division events leading to the appearance of small spherical chromosome-less cells together with filamentous cells of variable lengths (Adler et al., 1967).

Non-nucleate or minicell-like elements also appear in certain $E$. coli temperature-sensitive cell-division mutants at the non-permissive temperature (Hirota et al., 1968; Howe \& Mount, 1975; Gudas, 1976; Mulder \& Woldringh, 1989). This also occurs after exposure of DNA-repair mutants to nalidixic acid, especially in those defective in the $\operatorname{rec} A$ function (Inouye, 1971). Segregation of plasmids into these non-viable cells has never been evaluated.

Exposure of $E$. coli to the majority of curing agents, including DNA gyrase inhibitors, generally leads to the formation of filamentous cells (Diver \& Wise, 1986). Since this very feature might modify the spatial location of the plasmids, such morphological abnormalities may well be involved in plasmid loss.

The present study was undertaken to investigate the stability of the $F^{\prime} l a c$ episome in $E$. coli cells induced either to form filaments, or to grow as cocci. The experimental approach exploits the properties of $E$. coli 
strain SP45, a temperature-conditional mutant for the synthesis of $p b p A 45$ (Ts) (Spratt et al., 1980). Inactivation of $p b p A 45(\mathrm{Ts})$ at the nonpermissive temperature results in the growth of bacteria as large spherical cells that cannot elongate even if exposed to beta-lactam antibiotics or agents affecting DNA metabolism which generally cause filamentation in bacteria (Begg \& Donachie, 1985). At the permissive temperature, SP45 behaves as a normal rod which changes its shape only if subjected to the treatments mentioned above.

The role of the cell envelope in $\mathrm{F}^{\prime}$ lac maintenance was also evaluated in experiments carried out with $E$. coli strains defective in dnaA46(Ts), lexA41(Ts) and recA13 functions. The dnaA46(Ts) mutant stops DNA synthesis at $42{ }^{\circ} \mathrm{C}$, but continues to divide, and forms anucleate cells (Hirota et al., 1968; Mulder \& Woldringh, 1989). The lexA4I(Ts) mutant expresses SOS response and forms non-septated filaments at $42^{\circ} \mathrm{C}$ even though DNA synthesis is normal (Gudas, 1976).

Finally, the stability of $F^{\prime} l a c$ was investigated in E. coli gyrA43(Ts) and gyrB41(Ts) mutants and in their rodA51 derivatives. These thermosensitive DNA gyrase strains exhibit a phenotype reminiscent of minicell-producing strains. At the non-permissive temperature these $g y r$ mutants generate minicells and anucleate rods of variable lengths and show an irregular nucleoid distribution in filaments (Orr et al., 1979; Jaffé et al., 1988; Mulder et al., 1990). In contrast, the rodA51 derivatives grow as spherical cells in all experimental conditions. These experiments were prompted by the observations of Wolfson et al (1982) who described the elimination of two plasmids from $E$. coli with a thermolabile gyrase at semipermissive temperature, establishing the requirement of a functioning gyrase B subunit for plasmid maintenance.
The stability of plasmids carrying (pXX333) and lacking (pXX332) the $c c d$ function of the $F$ plasmid (Ogura \& Hiraga, 1983; Jaffé et al., 1985) was also evaluated in the thermolabile gyrase A and B subunit mutants and in their rodA51 derivatives.

\section{Methods}

Bacterial strains. Bacterial strains used in this study are listed in Table 1. The P1 transduction protocol used in strain construction was described by Miller (1972). The rodA51 gene was transduced using selection for mecillinam resistance $\left(20 \mu \mathrm{g} \mathrm{ml}^{-1}\right)$. The sulB25 gene was transduced into lexA4I(Ts) from a spontaneous azide-resistant PM161 strain, and thermoresistant mutants from among azide-resistant transductants.

Plasmid $F^{\prime}$ lac $\left(F^{\prime} 128\right)$ was one of the $F^{\prime}$ kit kindly provided by $B$. Bachmann; a Tn5-carrying derivative was constructed in order to simplify its identification in different hosts and selection of transconjugants in mating experiments. The transposon $\operatorname{Tn} 5$ encodes kanamycin-neomycin resistance. Plasmids pXX332 and pXX333 were described and kindly supplied by A. Jaffé (1985). Both plasmids are unable to replicate at $42^{\circ} \mathrm{C}$ and carry a gene conferring chloramphenicol resistance. pXX333, but not pXX332, carries the $c c d$ function of the mini-F plasmid pSC138 (Timmis et al., 1975). These plasmids were introduced into bacterial cells by transformation.

Susceptibility tests. The Minimum Inhibitory Concentration (MIC) of each compound employed in this study was performed in microtitre trays using Mueller-Hinton Broth (Difco), adjusted to $\mathrm{pH} 7.6$ when necessary, as previously described (Debbia et al., 1988).

Methods for plasmid elimination. Bacteria were grown overnight in Mueller-Hinton Broth (MHB) containing kanamycin $\left(25 \mu \mathrm{g} \mathrm{ml}^{-1}\right)$ to ensure $\mathrm{F}^{\prime}$ lac presence. Under these conditions the percentage of plasmid-free cells was lower than $0.1 \%$. After the drug was removed by washing the cells in saline buffer, about $5 \times 10^{3}$ bacteria were cultured in a series of tubes containing $1 \mathrm{ml} \mathrm{MHB}$ and various concentrations of the curing agent. A tube of drug-free MHB was used as a control.

After incubation for 18-20 $\mathrm{h}$ at the required temperature, a direct microscopical observation of bacterial cultures was done. Suspensions

Table 1. E. coli strains used

\begin{tabular}{|c|c|c|}
\hline $\begin{array}{l}\text { SP45 } \\
\text { CTR4610 } \\
\text { DM936 } \\
\text { PAM161 } \\
\text { db1413 } \\
\text { AB1157 } \\
\text { AB2463 } \\
\text { S1 } \\
\text { N4177 } \\
\text { db1589 } \\
\text { KNK453 } \\
\text { db1588 } \\
\text { pop3208 } \\
\text { db1590 } \\
\text { J-53 }\end{array}$ & $\begin{array}{l}\text { pbpA45(Ts), trp(Am), tyr(Am), ilv, supD126(Ts). } \\
\text { dnaA46(Ts), leu, thy, thi. } \\
\text { lexA41(Ts), ara-14, argE3, leuB6, } \triangle(\text { gpt-proA }) 62, \text { thr-1, recA1, rpsL31, galK2, } \\
\text { kdgK51, lexA3? } \\
\text { ara-14, sulB25, leuB6, } \Delta(\text { gpt-proA }) 62, \text { thr-1, rpsL31, galK2, lon-22, hisG4, } \\
\text { metF24, thi-1, lacY1, } \\
\text { same as DM936 but sulB25 } \\
\text { thr-1, leuB6, proA2, argE3, his-4, thi-1, lacY1, galK2, rpsL31 } \\
\text { recA13 derivative of AB1157 } \\
\text { proA2, rodA51, purB15, hisG4, lacY1, galK2, xyl-5, rpsL35 } \\
\text { galK, gyrB41(Ts) } \\
\text { same as N4177 but rodA51 } \\
\text { HF4704 gyrA43(Ts), thyA, polA, uvrA, phx } \\
\text { same as KNK453 but rodA51 } \\
\text { araD139, } \Delta(\text { argF-lac)205, flbB5301, ptsF25, relA1, rpsL150, lamB204 deoC1 } \\
\text { same as pop3208 but rodA5I } \\
\text { pro22, metF63 }\end{array}$ & $\begin{array}{l}\text { B. G. Spratt (1980) } \\
\text { Y. Hirota (1968) via G. Satta (1978) } \\
\text { D. Mount (1975) via B. J. Bachmann } \\
\text { B. F. Johnson (1977) via B. J. Bachmann } \\
\text { This work } \\
\text { P. Howard-Flanders (1966) via C. Monti-Bragadin } \\
\text { P. Howard-Flanders (1966) via C. Monti-Bragadin } \\
\text { H. Matsuzawa (1973) via B. J. Bachmann } \\
\text { Menzel \& Gellert (1983) via B. J. Bachmann } \\
\text { This work } \\
\text { K. Kreuzer (1979) via C. Monti-Bragadin } \\
\text { This work } \\
\text { B. J. Bachmann } \\
\text { This work } \\
\text { B. J. Bachmann }\end{array}$ \\
\hline
\end{tabular}


showing bacteria with morphological changes were then diluted 100fold in pre-warmed drug-free medium and incubated for $90 \mathrm{~min}$ at the appropriate temperature. Controls were diluted similarly. Bacteria were diluted further in saline buffer and plated on drug-free MuellerHinton agar (MHA). After incubation for $18-20 \mathrm{~h}$, colonies were replicated onto drug-free and antibiotic-containing MHA using velvets. Growth on antibiotic-containing media indicated the presence of the plasmid encoding that resistance. In some cases the presence of $F^{\prime} l a c$ was detected by determining the susceptibility of the cells to the sex-specific phage MS2 or by scoring the lactose-positive colonies on McConkey agar plates. The number of colonies on drug-containing plates was expressed as a fraction of the number on drug-free plates.

Cultures of gyrA43(Ts), gyrA43(Ts)(rodA5I), gyrB4I(Ts) and gyrB4I(Ts)(rodA5l) carrying either pXX332 or pXX333 were incubated overnight at $28^{\circ} \mathrm{C}$ in the presence of chloramphenicol $\left(20 \mu \mathrm{g} \mathrm{ml}^{-1}\right)$. They were then diluted 1000-fold in fresh prewarmed LB medium [per litre: tryptone (Difco), $10 \mathrm{~g}$; yeast extract, $5 \mathrm{~g} ; \mathrm{NaCl}, 5 \mathrm{~g}$ ] and transferred to the semipermissive temperature $\left(36.5^{\circ} \mathrm{C}\right)$. Control cultures were incubated at $28^{\circ} \mathrm{C}$. Samples were taken at appropriate intervals and spread onto LB agar plates. Colonies were scored after incubation at $28^{\circ} \mathrm{C}$. The presence of plasmids in bacteria was detected by replica plating onto chloramphenicol-containing LB agar.

Separation of non-nucleated cells. Non-nucleated cells were prepared by differential centrifugation and sucrose gradient (Levy, 1970). Briefly, $400 \mathrm{ml}$ culture were centrifuged at $1500 \mathrm{~g}$ for $5 \mathrm{~min}$. The supernatant was sedimented at $10000 \mathrm{~g}$ for $15 \mathrm{~min}$. The pellet was resuspended in $4 \mathrm{ml} 0.05 \mathrm{M}$-sodium phosphate, $\mathrm{pH} 7$. Samples $(2 \mathrm{ml})$ were layered on top of a $25 \mathrm{ml}$ sucrose gradient prepared by dispensing $25 \mathrm{ml}$ of $20 \%(\mathrm{w} / \mathrm{v})$ sucrose solution into a $30 \mathrm{ml}$ glass centrifuge tube, freezing the gradient at $-20^{\circ} \mathrm{C}$ and then thawing it at $4{ }^{\circ} \mathrm{C}$ overnight. The gradients were centrifuged for $40 \mathrm{~min}$ at $2500 \mathrm{~g}$. The non-nucleated cells appeared as a broad band in the upper half of the tube. These were recovered, collected by centrifugation and further purified by a second sucrose gradient. The final band of non-nucleated cells was treated with ampicillin $\left(200 \mu \mathrm{g} \mathrm{ml}^{-1}\right)$ to eliminate contaminating nucleated cells.

Plasmid transfer. General mating conditions for evaluating plasmid transfer followed those outlined by Willetts (1988). Plasmid transfer from minicell-like elements was carried out in liquid medium. Donors $(0.2 \mathrm{ml})$ were mixed with $0.2 \mathrm{ml}$ culture $\left(2 \times 10^{8}\right.$ cells per ml $)$ of a nalidixic-acid-resistant derivative of strain J-53. After $90 \mathrm{~min}$ of incubation at the appropriate temperature, the mixture was plated on selective media. The number of viable bacteria was determined by plating the diluted culture on LB agar. The number of non-viable cells was estimated by microscopical observation in a Petroff-Hausser chamber.

\section{Results}

Evaluation of F'lac elimination from SP45 strain grown at permissive and non-permissive temperatures

In preliminary tests, SP45 harbouring the F'lac plasmid, grown at the permissive temperature, was exposed to subinhibitory concentrations of various chemicals, including the well-known curing agents acridine orange and ethidium bromide. Among those that, irrespective of their mode of action, produced morphological alterations in bacteria, some representative compounds were chosen for further testing. Piperacillin, chlorohexidine, polymyxin $B$, and sodium azide were studied because their ability to cure plasmids has not been previously described. Nalidixic acid, ciprofloxacin and acridine orange were tested because they are considered selective inhibitors of plasmid DNA replication, and mecillinam because it induces spherical forms.

After incubation at $30^{\circ} \mathrm{C}$ for $18 \mathrm{~h}$, a microscopic examination of the culture revealed the presence of elongated or round forms in test tubes containing drug concentrations near the MIC values (0.5-0.25 $\times$ MIC depending on the compound tested). Filaments produced by piperacillin were very long in comparison to those produced by the other compounds which were equivalent in length to 3-4 cells. As expected, spheres were present in the samples containing mecillinam (Spratt et al., 1980).

Survivors from those concentrations affecting bacterial shape were then plated on antibiotic-free medium and tested for plasmid traits. The number of microorganisms in control cultures ranged from $4 \times 10^{8}$ to $1.3 \times 10^{9}$ c.f.u. $\mathrm{ml}^{-1}$ (18 to 21 generations of growth) and in the treated cultures from $4 \times 10^{8}$ to $9 \times 10^{8}$ c.f.u. $\mathrm{ml}^{-1}$ (18-20 generations of growth).

The results of these experiments (Table 2) demonstrate that the chemical agents used, with the exception of mecillinam, were able to promote the loss of $\mathrm{F}^{\prime}$ lac from the cells. When the same experiments were carried out at $42^{\circ} \mathrm{C}$, bacteria were pre-incubated for $90 \mathrm{~min}$ to allow the cells to undergo a rod-sphere transition. Following this, they were treated with the same compounds used at $30{ }^{\circ} \mathrm{C}$. The resident $\mathrm{F}$ plasmid was not cured from SP45 at $42{ }^{\circ} \mathrm{C}$ even if the host was treated with the same amounts of chemicals which cause $F^{\prime}$ lac loss from the same strain at the permissive temperature. These data suggest that plasmid maintenance in bacteria might be compromised by agents that cause elongation of the cell envelope. In contrast, the selective block of lateral wall extension seems not to influence the stability of the plasmid.

\section{Evaluation of $\mathrm{F}^{\prime}$ lac elimination from various hosts}

Further evidence for the role of the cell envelope in plasmid maintenance was obtained in experiments carried out with strains defective in $d n a A, \operatorname{lexA}$ or rec $A$ functions and carrying $F^{\prime} l a c$ (Table 3 ). Plasmid curing was observed with the dnaA46(Ts) mutant after incubation of the culture at $42{ }^{\circ} \mathrm{C}$ for $3 \mathrm{~h}$ but not when this strain was grown at the permissive temperature. $\mathrm{F}^{\prime}$ lac curing was also observed in the lexA4I(Ts) mutant after $3 \mathrm{~h}$ at the non-permissive temperature, but not in the control sample, or in its sulB25 derivative, under the same experimental conditions, or after incubation at $42^{\circ} \mathrm{C}$ for a further $18 \mathrm{~h}$ (data not shown). Furthermore, when a recA13 mutant was treated with nalidixic acid, filaments 
Table 2. Effect of various chemicals on F'lac stability and on bacterial growth in E. coli SP45

\begin{tabular}{|c|c|c|c|c|c|}
\hline \multirow[b]{2}{*}{ Compound } & \multirow{2}{*}{$\begin{array}{c}\mathrm{MIC} \\
\left(\mu \mathrm{g} \mathrm{ml}^{-1}\right)\end{array}$} & \multirow{2}{*}{$\begin{array}{l}\text { Bacterial shape at the } \\
\text { indicated sub-MIC } \\
\left(\mu \mathrm{g} \mathrm{ml}^{-1}\right)^{*}\end{array}$} & \multicolumn{2}{|c|}{$\begin{array}{l}\text { Cured cells }(\%) \text { obtained } \\
\text { from bacteria with altered } \\
\text { shape at temperature } \dagger\end{array}$} & \multirow{2}{*}{$\begin{array}{l}\text { Number of } \\
\text { cells examined }\end{array}$} \\
\hline & & & $30^{\circ} \mathrm{C}$ & $42^{\circ} \mathrm{C}$ & \\
\hline Piperacillin & 1 & long filaments $(0.25)$ & 27 & 0 & 937 \\
\hline Chlorohexidine & 0.25 & short filaments $(0.12)$ & 21 & 0 & 1361 \\
\hline Polymyxin & $0 \cdot 12$ & short filaments $(0.08)$ & 15 & 0 & 1107 \\
\hline Sodium azide & 50 & short filaments $(12 \cdot 5)$ & 16 & 0 & 867 \\
\hline Nalidixic acid & 4 & long filaments $(1 \cdot 5)$ & 24 & 0 & 2036 \\
\hline Ciprofloxacin & 0.01 & long filaments $(0.005)$ & 47 & 0 & 1483 \\
\hline Acridine orange & 20 & short filaments (10) & 22 & 0 & 856 \\
\hline Mecillinam & 2 & $\operatorname{cocci}(0 \cdot 5)$ & 0 & 0 & 1214 \\
\hline None & & rods & 0 & 0 & 1664 \\
\hline
\end{tabular}

* At the permissive temperature.

$\dagger$ Data are means of 3 experiments.

Table 3. Effect of bacterial mutations on the stability of $F^{\prime}$ lac and susceptibility of some strains to nalidixic acid (nal)

\begin{tabular}{|c|c|c|c|c|c|}
\hline \multirow[b]{2}{*}{ Mutation } & \multicolumn{2}{|c|}{ Treatment } & \multirow{2}{*}{$\begin{array}{c}\text { Cured cells } \\
(\%)^{* *}\end{array}$} & \multirow{2}{*}{$\underset{\left(\mu \mathrm{g} \mathrm{ml}^{-1}\right)}{\mathrm{MIC}}$} & \multirow{2}{*}{$\begin{array}{l}\text { Number of } \\
\text { cells examined }\end{array}$} \\
\hline & Temp. $\left({ }^{\circ} \mathrm{C}\right)$ & Drug ( $\mu \mathrm{g} \mathrm{ml}^{-1}$ ) & & & \\
\hline$d n a A 46(\mathrm{Ts})$ & 32 & - & 0 & - & 762 \\
\hline dnaA46(Ts) & 43 & - & 23 & - & 938 \\
\hline lexA4I(Ts) & 32 & - & 0 & - & 1074 \\
\hline lexA41(Ts) & 43 & - & 27 & - & 1248 \\
\hline lexA4I(Ts) sulB25 & 32 & - & 0 & - & 654 \\
\hline lexA41(Ts) sulB 25 & 43 & - & 0 & _- & 1332 \\
\hline $\operatorname{recA13}$ & 37 & 0 & 13 & - & 595 \\
\hline recA13 & 37 & $\operatorname{nal}(0 \cdot 25)$ & 49 & 1 & 826 \\
\hline$r e c A^{+*}$ & 37 & $\operatorname{nal}(1 \cdot 5)$ & 28 & 4 & 1388 \\
\hline
\end{tabular}

appeared, but septation and division occurred at a higher rate than in either $d n a A 46(\mathrm{Ts})$ or lexA41(Ts) mutants (Inouye, 1971). The recA13 strain lost $\mathrm{F}^{\prime}$ lac when treated with a drug concentration which did not significantly affect bacterial growth $(0.25 \times \mathrm{MIC})$. Spontaneous plasmid loss was also observed with the recAl3 strain.

Surprisingly, the curing effect could be achieved with different concentrations of nalidixic acid. $F^{\prime} l a c$ was eliminated from strain SP45 at $30^{\circ} \mathrm{C}$ at the same nalidixic acid concentration $\left(1.5 \mu \mathrm{g} \mathrm{ml}^{-1}\right)$ as that used to obtain the equivalent rate of curing in the control strain $\mathrm{AB} 1157\left(\mathrm{~F}^{\prime}\right.$ lac). No curing was observed in the pbpa45(Ts) mutant strain at $42^{\circ} \mathrm{C}$ in the presence of $1.5 \mu \mathrm{g}$ nalidixic acid $\mathrm{ml}^{-1}$, but $\mathrm{F}^{\prime}$ lac was lost from the recA13 mutant in the presence of $0.25 \mu \mathrm{g} \mathrm{ml}^{-1}$ of the drug. If the mechanism by which nalidixic acid promotes the loss of the episome from the cells is the preferential inhibition of plasmid replication, curing might have been expected under all the experimental conditions employed, and at the lowest drug concentration. Since this was not the case, factors other than plasmid replication might be involved in curing by nalidixic acid.

Further clues, which seem to exclude the possibility that this DNA gyrase inhibitor affects plasmid replication, comes from experiments performed with $\mathrm{Hfr}$ strains selected by integrative suppression in a dnaA mutant. In these $\mathrm{Hfr}$ strains at high temperature, chromosome replication and cell division are under control of the F plasmid. Nishimura et al. (1971) and Bazzicalupo \& Tocchini-Valentini (1972) have shown that acridine orange and rifampin, respectively, inhibit cell division at $43^{\circ} \mathrm{C}$ in these strains, providing evidence that the $F$ replication system is sensitive to these chemicals. In contrast, when the same experiments were carried out with nalidixic acid, no changes were found in the MIC values of the $\mathrm{Hfr}$ strains at both 30 and $42^{\circ} \mathrm{C}$ (Table 4). 
Table 4. Effect of nalidixic acid (Nal) on Hfr strains*, selected by integrative suppression in a dnaA46 mutant sensitive to both acridine orange $(A O)$ and rifampicin (Rif)

\begin{tabular}{|c|c|c|c|c|c|c|c|c|c|c|}
\hline & \multicolumn{5}{|c|}{$30^{\circ} \mathrm{C}$} & \multicolumn{5}{|c|}{$43^{\circ} \mathrm{C}$} \\
\hline & Control & $\begin{array}{c}\mathrm{AO} \\
\left(20 \mu \mathrm{g} \mathrm{ml}^{-1}\right)\end{array}$ & $\begin{array}{c}\text { Rif } \\
\left(1 \mu \mathrm{g} \mathrm{ml}^{-1}\right)\end{array}$ & \multicolumn{2}{|c|}{ Nal } & Control & $\begin{array}{c}\mathrm{AO} \\
\left(20 \mu \mathrm{g} \mathrm{ml}^{-1}\right)\end{array}$ & $\begin{array}{c}\text { Rif } \\
\left(1 \mu \mathrm{g} \mathrm{ml}^{-1}\right)\end{array}$ & \multicolumn{2}{|c|}{ Nal } \\
\hline Hfr 1 & + & + & + & + & - & + & - & - & + & - \\
\hline Hfr 2 & + & + & + & + & - & + & - & - & + & - \\
\hline Hfr 3 & + & + & + & + & - & + & - & - & $t$ & - \\
\hline
\end{tabular}

* Representative of $27 \mathrm{Hfr}$ strains isolated.

Evaluation of $F^{\prime}$ lac elimination from bacteria temperature-sensitive in the $A$ and $B$ subunits of DNA gyrase

KNK453 [gyrA43(Ts)], db1588 [gyrA43(Ts)(rodA51)], $\mathrm{N} 4177$ [gyrB41(Ts)] and db1589 [gyrB41(Ts) $(\operatorname{rodA51})]$ strains carrying $\mathrm{F}^{\prime}$ lac were cultured at permissive $\left(28^{\circ} \mathrm{C}\right)$ and semipermissive $\left(36.5^{\circ} \mathrm{C}\right)$ temperatures. In KNK453 and $\mathrm{N} 4177$, cured cells were found after 1 generation, and at the end of the experiment they represented 75 and $95 \%$ respectively of the total bacteria. Viable plasmidfree segregants were also detected after 1 generation in the cultures of db1588 and db1589, but their number was about $20 \%$ of the total bacterial population after 8 generations (Fig. 1). This finding indicated that plasmid stability might be affected by thermal inactivation of gyrase A and B subunits, but the elongation of the bacterial envelope induced by these mutations played a determinant role in the $F^{\prime}$ lac curing process. When filament formation was prevented by the $\operatorname{rod} A 51$ mutation, plasmid maintenance was improved.

\section{Evaluation of $p X X 332$ and $p X X 333$ elimination from} bacteria temperature-sensitive in the $A$ and $B$ subunits of DNA gyrase

As established by Jaffé et al. (1985) the $c c d$ (coupled cell division) function of $F$ plasmid inhibits the segregation of viable plasmid-free cells in $E$. coli. The $c c d$ locus in fact causes filamentous growth of the $\mathrm{F}^{-}$derivative and so causes cell death. The similarities between the morphological abnormalities in cell growth induced by the $c c d$ function and the agents or the mutations that promote plasmid loss prompted an investigation of the stability of pXX332 $\left(c c d^{-}\right)$and pXX333 $\left(c c d^{+}\right)$in KNK453 and $\mathrm{N} 4177$, and in their rodA51 derivatives db1588 and db1589 respectively.

In kinetic studies performed at $36.5^{\circ} \mathrm{C}$ (Fig. $2 a$ ), both pXX332 and pXX333 were eliminated after 2 generations from KNK453 and after 5 generations from db1588. The growth rates of rods were $54 \mathrm{~min}$ per generation (pXX332) and $58 \mathrm{~min}$ per generation (pXX333), and those of cocci 58 min per generation (pXX332) and 60 min per generation (pXX333). Plasmid-free segregants were not found in rod and spherical cells grown at $28^{\circ} \mathrm{C}$ after the same number of generations (data not shown).
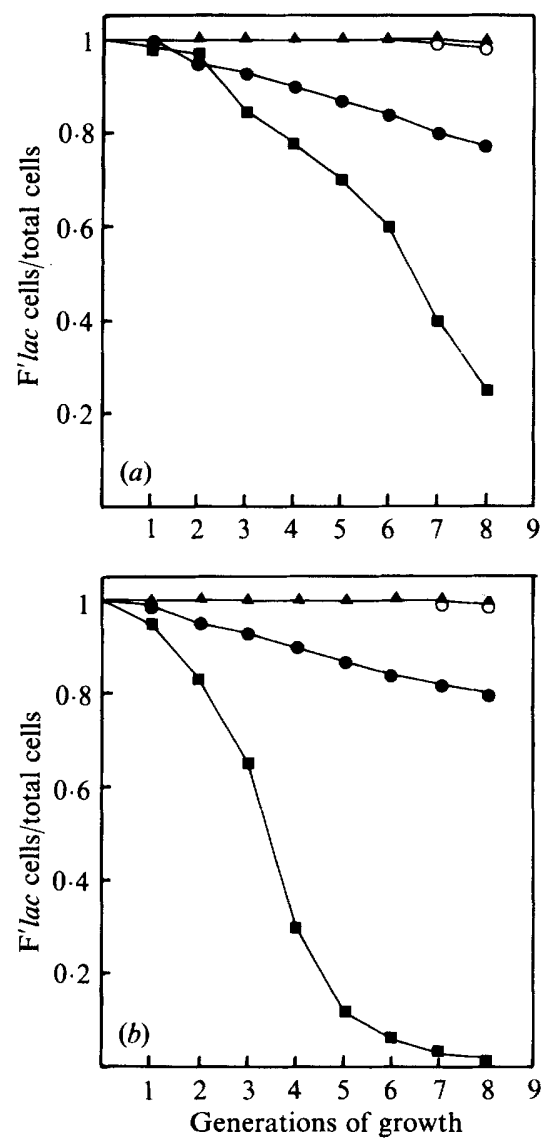

Fig. 1. Kinetics of elimination of $F^{\prime}$ lac from DNA gyrase mutants and their rodA51 derivatives. (a) $\square, \mathrm{KNK} 453\left(\mathrm{~F}^{\prime} l a c\right)$; $\bullet$, db1588( $\left.\mathrm{F}^{\prime} l a c\right)$ grown at $36.5^{\circ} \mathrm{C}$; and $\Delta, \mathrm{KNK}^{\circ} 53\left(\mathrm{~F}^{\prime}\right.$ lac $) ; \mathrm{O}, \mathrm{db} 1588\left(\mathrm{~F}^{\prime}\right.$ lac $)$ grown at $28^{\circ} \mathrm{C}$. (b) $\boldsymbol{B}, \mathrm{N} 4177\left(\mathrm{~F}^{\prime} l a c\right) ; \bullet, \mathrm{db} 1589\left(\mathrm{~F}^{\prime} l a c\right)$ grown at $36.5^{\circ} \mathrm{C}$; and $\mathbf{\Delta}$, $\mathrm{N} 4177\left(\mathrm{~F}^{\prime}\right.$ lac $) ; \mathrm{O}, \mathrm{db} 1589\left(\mathrm{~F}^{\prime} l a c\right)$ grown at $28^{\circ} \mathrm{C}$. 

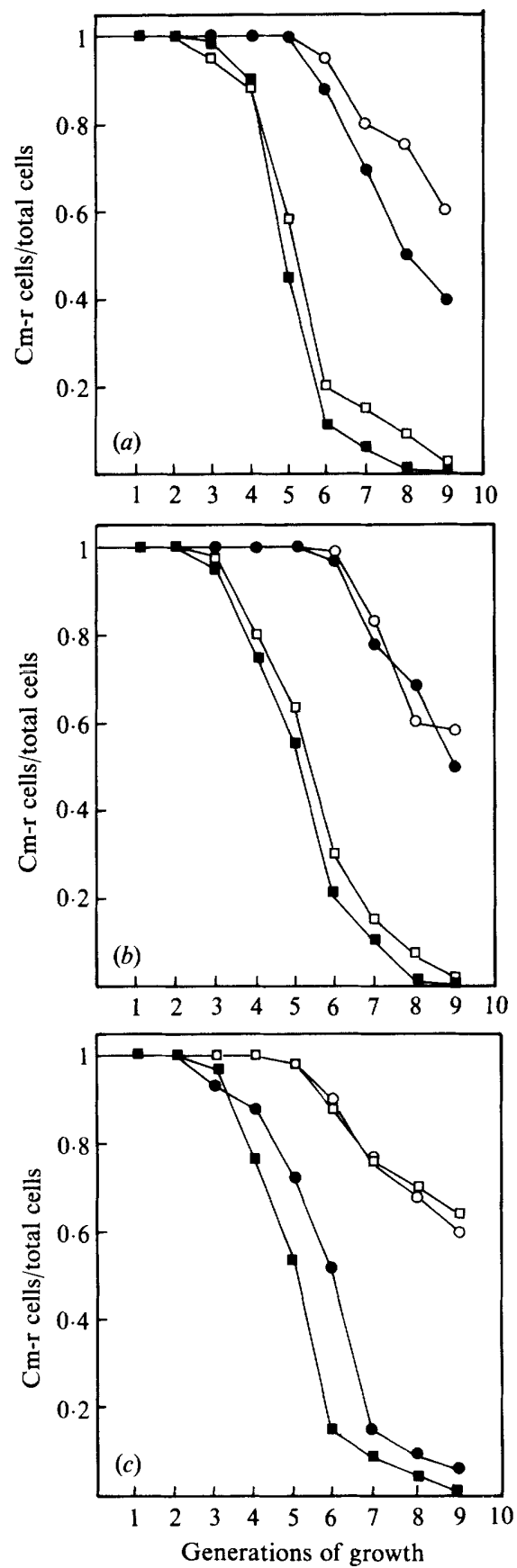

Fig. 2. Kinetics of elimination of pXX332 (filled symbols) and pXX333 (open symbols) from DNA gyrase mutants and their rodA51 derivatives. (a) $\square, \square, \mathrm{KNK} 453$; and $\bullet, O$, db1588 grown at $36.5^{\circ} \mathrm{C}$. (b) $\boldsymbol{\square}, \square, \mathrm{N} 4177$; and $\bullet, O, \mathrm{db} 1589$ grown at $36.5^{\circ} \mathrm{C}$. (c) $\square, \square$, pop3208; and $\bullet, O \mathrm{db} 1590$ grown at $42{ }^{\circ} \mathrm{C}$. Control cultures grown at permissive temperature were also studied (data not shown).

Results obtained with N4177 (Fig. 2b) demonstrated plasmid elimination after 2.5 generations from $g y r B 41$ (Ts), and after 6 generations from the gyrB4l(Ts)$(\operatorname{rod} A 51)$ double mutant incubated at $36.5^{\circ} \mathrm{C}$. After 9 generations, the percentage of cured cells was greater than $99.9 \%$ in the rods and about $55 \%$ in the spherical cells. No marked difference was found in the curing rate between mini-F plasmids carrying (pXX333) and lacking (pXX332) the $c c d$ genes. The generation times calculated for all the cultures were $48 \mathrm{~min}$ per generation (pXX332) and $50 \mathrm{~min}$ per generation (pXX333) in rods, and $51 \mathrm{~min}$ per generation, (pXX332) and 55 min per generation (pXX333) in rodA51 mutants. Plasmid-free bacteria were not found in spherical cells at $28{ }^{\circ} \mathrm{C}$, while about $7 \%$ of plasmid-free segregants were noted in rods after the same number of generations (data not shown).

A direct microscopical observation of the cultures grown at $36.5^{\circ} \mathrm{C}$ revealed the presence of elongated forms after about $2 \mathrm{~h}$ incubation in NKN453 and N4177 carrying either $\mathrm{pXX} 332$ or $\mathrm{pXX} 333$.

To determine whether, under the same growth conditions, pXX332 and pXX333 are stably inherited in strains other than DNA gyrase mutants, pop3208 and its rodA51 derivative (db1590) harbouring the above plasmids were grown at $36.5^{\circ} \mathrm{C}$. Plasmid-free segregants were not found after 9 generations in any of the cultures (data not shown).

These tests were also performed at the restrictive temperature $\left(42^{\circ} \mathrm{C}\right)$ for the replication of the plasmids. The kinetics of elimination of pXX332 and pXX333 from pop3208 and db1590 cultured at $42{ }^{\circ} \mathrm{C}$ revealed that pXX332-free cells first appeared after 2 generations and their number increased rapidly. After 9 generations, more than $99 \%$ of the bacterial population had lost the plasmid (Fig. 2c). When the cultures of $\operatorname{rod} A^{+}$and rodA51 strains harbouring $\mathrm{pXX} 333$ were grown under the same conditions, plasmid-free segregants appeared after 4 generations and although the number of colony formers remained nearly constant, at the end of the experiment the fraction of viable plasmid-carrying cells was about $60 \%$ (pop3208) and $64 \%(\mathrm{db} 1590)$ of the survivors.

Therefore pXX333 was eliminated at about the same rate from rods and cocci at the non-permissive temperature. As expected (Jaffé et al., 1985), the number of pXX333-free cells was lower than that observed with pXX332, because the $c c d$ function of $F$ produced lethal effects on both rods and coccal plasmid-free segregants.

\section{Segregation of $F^{\prime}$ lac in minicell-like elements}

As reported above, cell elongation per se seems to play an important role in plasmid elimination. Since filament formation is followed by the production of DNA-less cells especially in dnaA46(Ts) mutants and in cells exposed to nalidixic acid, segregation of plasmids in these non-viable elements was evaluated.

These non-viable cells were sought in bacterial cultures processed for plasmid elimination employing 
Table 5. Transfer of $F^{\prime}$ lac from the ampicillin fraction of treated and untreated cultures

\begin{tabular}{lcccc}
\hline \hline Donors & Treatment & $\begin{array}{c}\text { Total viable cells } \\
\text { (c.f.u. ml }\end{array}$ & $\begin{array}{c}\text { Non-viable } \\
\text { elements }\end{array}$ & Recombinants \\
\hline dnaA46(Ts) & none & $9 \times 10^{3}$ & $<5.4 \times 10^{4}$ & $<10$ \\
dnaA46(Ts) & $43^{\circ} \mathrm{C}$ & $4 \times 10^{3}$ & $3.2 \times 10^{7}$ & 753 \\
AB1157 & none & $<1 \times 10^{3}$ & $<5.4 \times 10^{4}$ & $<10$ \\
AB1157 & nal & $8.8 \times 10^{4}$ & $4.3 \times 10^{7}$ & 2850 \\
AB1157* & none & $5 \times 10^{4}$ & - & $<10$ \\
\hline \hline
\end{tabular}

* Original culture diluted at the indicated cell number per ml.

sucrose gradient followed by ampicillin enrichment. $\mathrm{AB} 1157\left(\mathrm{~F}^{\prime} \mathrm{lac}\right)$ was exposed to $1.5 \mu \mathrm{g}$ nalidixic acid $\mathrm{ml}^{-1}$, and $d n a A 46(\mathrm{Ts})\left(\mathrm{F}^{\prime} l a c\right)$ was cultured at $42^{\circ} \mathrm{C}$ for $3 \mathrm{~h}$. The final pellet from treated and control cultures, obtained after ampicillin enrichment, was resuspended in $2 \mathrm{ml}$ buffer. Recovery of biologically functional $\mathrm{F}$ factor from these preparations in the absence of viable bacterial cells would provide the most compelling evidence for the presence of plasmids in minicell-like elements. The purified minicell suspensions were mated with a recipient strain and exconjugants were sought by plating the mixture on appropriate selective media. As reported in Table 5, plasmid transfer occurs from both treated cultures. No recombinants were obtained under these experimental conditions from the suspensions of the control strains. In addition, the evaluation of viable and non-viable bacteria in all the samples showed that they contained about the same number of survivors. A great number $\left(3 \cdot 2-4 \cdot 3 \times 10^{7}\right)$ of non-viable elements was found in the suspensions of treated cultures when compared to the control $\left(<5.4 \times 10^{4}\right)$.

The possibility that donor ability resided in viable bacteria was also explored using an appropriate dilution of the original culture of $\mathrm{AB} 1157\left(\mathrm{~F}^{\prime}\right.$ lac $)$. The results indicate that this was not so. No plasmid was transferred to the recipient strain from a low number of donor cells equivalent to that of survivors after the purification step. These findings indicate that treated cultures contain a number of non-nucleated cells carrying the $F^{\prime}$ factor which are not present in the control strains.

\section{Discussion}

Plasmid elimination as the direct consequence of the elongation of bacterial cells appears to be the most striking observation in this study. The effect of shape alterations on plasmid stability was demonstrated in experimental conditions under which elongated or spherical cells resulted either from the presence of a bacterial mutation or the mode of action of a drug. No curing was found under these conditions in spherical cells or in bacteria where filamentation was prevented. In contrast, a high percentage of plasmid-free bacteria was obtained from cells capable of undergoing filament transition.

The asymmetrical cell division that follows the elongation of the cells can be envisaged to be the second factor playing an important role in the curing process. This paper demonstrates, in fact, that the curing process is the result of plasmid segregation into minicell-like elements.

It has been reported that curing is achieved in experimental conditions which still permit cell growth (Weisser \& Wiedemann, 1985; Michel-Briand et al., 1986). These observations suggest that the effects caused by the curing agents are rapidly overcome by bacteria which are thus able to divide (Engle et al., 1982). During filament formation, chromosomal and plasmid DNA might be found at opposite extremities of the elongated cells. If septa are then formed plasmid and chromosomal DNA will segregate in different cellular units.

The proposed plasmid-curing process presents many analogies with that concerning the segregation of plasmid into minicells (Rashtchian et al., 1986). In particular, some investigators have demonstrated that plasmids during part of their life cycle might be bound to the bacterial membrane or might be associated with the folded chromosome or may reside in both positions (Jacob et al., 1963; Kline \& Miller, 1979; Rashtchian et al., 1986). This suggests that the ability of plasmids to segregate into minicells is related to their spatial location. Therefore, the probability that a curing agent has of eliminating an extrachromosomal element from its host might depend on the plasmid being bound to the membrane or associated with the folded chromosome. In particular, the former localization will favour plasmid curing, while the latter will not. On the other hand, multicopy plasmids or those located in both positions should have a lower tendency to be lost. This model explains how different chemical compounds that induce filament formation determine plasmid loss, and why the same effect is not achieved when treated bacteria are induced to a coccal shape. Preliminary results obtained 
in this laboratory have shown that plasmids R387 (IncK), RN3 (IncN), R386 (IncFI), R391 (IncJ), R16 (IncO), R621a (IncI), but not RP4 (IncP-1) were lost from SP45 after filament induction, as described here, but not from the spherical cells.

In this context, it is worth noting that exposure of bacteria to DNA gyrase inhibitors leads to the induction of the recA gene product (Gudas \& Pardee, 1976) which is responsible for the elongation of the bacterial cells (Satta \& Pardee, 1978), a condition in which curing occurs. Thus, all the curing events induced by agents whose mechanisms of action are not known should be reconsidered, especially if morphological alterations are produced.

In considering $\mathrm{F}^{\prime}$ lac and $\mathrm{pXX} 332$ or $\mathrm{pXX} 333$ elimination mechanisms from DNA gyrase mutants and other bacterial hosts it is necessary to take into account the following observations: (i) $\mathrm{F}^{\prime}$ lac and $\mathrm{pXX} 332$ or $\mathrm{pXX} 333$ at $36.5^{\circ} \mathrm{C}$ are stably inherited in strains other than DNA gyrase mutants; (ii) the phenotype of gyrB4l(Ts) and gyr $A 43$ (Ts) at $36.5^{\circ} \mathrm{C}$ carrying or not carrying plasmids is reminiscent of that of some minicell-producing mutants; (iii) the rate of pXX332 or pXX333 elimination at $36.5^{\circ} \mathrm{C}$ from DNA gyrase mutants is dependent on host shape and is not affected by the presence of the $c c d$ function of F; (iv) the number of pXX332- and pXX333free segregants at $42^{\circ} \mathrm{C}$ from strains other than DNA gyrase mutants is dependent on the presence of the $c c d^{+}$ gene in the plasmid and is not related to host shape; (v) filaments induced by the $c c d$ function of $\mathrm{F}$ are present in plasmid-free segregants only when the replication of plasmid is blocked by the temperature; (vi) the mutation which renders bacteria able to grow as cocci does not affect plasmid stability per se.

Taken together these observations suggest that plasmid elimination from DNA gyrase mutants at semipermissive temperature occurs because, like minicell producing mutants, they present abnormalities in the division process which lead to the production of anucleated rods and minicells into which plasmids can segregate (Kass \& Yarmolinsky, 1970). The fact that in rodA51 derivatives, plasmid elimination is strongly reduced but not totally abolished, also suggests that DNA gyrases play a role in plasmid maintenance. Thus, cell elongation or the inactivation of these enzymes or both, influence plasmid stability in DNA gyrase mutants.

Another important factor known to influence plasmid maintenance in bacteria is the system for regulation of DNA replication (Scott, 1984). It has been demonstrated that acridine orange cures $F$ factor from cells by inhibiting plasmid replication (Hohn \& Korn, 1969; Wechsler \& Kline, 1980). However, the presence of elongated forms has also been noted here in acridine- orange-exposed cells, suggesting a possible involvement of bacterial shape as cofactor in this process.

The observations that nalidixic acid was unable to promote plasmid loss from round cells at the same concentration effective in curing plasmids in rods, and that it was not able to inhibit Hfr strains that grow under the control of $F$ replication system are of special interest. This behaviour strongly suggests that the mechanism by which nalidixic acid eliminates plasmids does not primarily affect plasmid replication.

Studies from this laboratory have shown that the replication of plasmid pSUP5011 (Simon, 1984) in starved cells is blocked by a concentration of cinoxacin two orders of magnitude greater than that required to inhibit cell growth (Debbia \& Schito, 1986). This is far higher than the concentration effective in plasmid curing under usual experimental conditions.

Differences in the susceptibility to oxolinic acid between plasmid and chromosome replication were also reported in other studies (Drlica, 1984). Additional experiments therefore seem to be required to elucidate the role of these DNA gyrase inhibitors in plasmid maintenance.

Finally, the above results might be of clinical significance. During antibiotic therapy, conditions for plasmid curing are easily achieved because bacteria are exposed to variable concentrations of drugs, some of these being more effective in curing than in others. Plasmids could therefore segregate in vivo into non-viable elements. Since these minicell-like units are no longer affected by antibiotics but are able to transfer plasmids, they might represent one factor contributing to plasmid dissemination.

I thank B. J. Bachmann and A. Jaffé for their generous contributions of bacterial strains and plasmids. I also thank G. C. Schito for encouragement and advice during the course of this work, and A. Inga and $\mathrm{A}$. Marchese who helped at various stages of this project.

\section{References}

Adler, H., Fisher, W., Cohen, A. \& Hardigree, A. (1967) Miniature E. coli cells deficient in DNA. Proceedings of the National Academy of Sciences of the United States of America 57, 321-326.

Bazzicalupo, P. \& Tocchini-Valentini, G. P. (1972). Curing of an Escherichia coli episome by rifampicin. Proceedings of the National Academy of Sciences of the United States of America 69, 298-300.

BeGG, K. J. \& DonACHIE, W. D. (1985). Cell shape and division in Escherichia coli: experiments with shape and division mutants. Journal of Bacteriology 163, 615-622.

Debbia, E. A. \& Schito, G. C. (1986). Isolation of a thermosensitive mutant of pBR325::Tn5-mob plasmid. Abstracts XIV International Congress of Microbiology, Manchester, England. P.B29-13, p. 133.

Debbia, E., Pesce, A. \& Schito, G. C. (1988). In vitro activity of LY146032 alone and in combination with other antibiotics against gram-positive bacteria. Antimicrobial Agents and Chemotherapy 32, 279-281. 
Diver, J. M. \& Wise, R. (1986). Morphological and biochemical changes in Escherichia coli after exposure of ciprofloxacin. Journal of Antimicrobial Chemotherapy 18, Supplement D, 31-41.

DrLICA, K. (1984). Biology of bacterial deoxyribonucleic acid topoisomerases. Microbiological Reviews 48, 273-289.

Engle, E. C., Manes, S. H. \& DrLica, K. (1982). Differential effects of antibiotics inhibiting gyrase. Journal of Bacteriology 149, 92-98.

GuDAS, L. J. (1976). The induction of protein X in DNA repair and cell division mutants of Escherichia coli. Journal of Molecular Biology 104, 567-587.

Gudas, L. J. \& PardeE, A. B. (1976). DNA synthesis inhibition and the induction of protein X in Escherichia coli. Journal of Molecular Biology 101, 459-477.

HiRota, Y., JACOB, F., RYter, A., Buttin, G. \& NAKAI, T. (1968). On the process of cellular division in Escherichia coli I: asymmetrical cell division and production of deoxyribonucleic acid-less bacteria. Journal of Molecular Biology 35, 175-192.

HOHN, B. \& KORN, D. (1969). Cosegregation of a sex factor with the Escherichia coli chromosome during curing by acridine orange. Journal of Molecular Biology 45, 385-395.

Hooper, D. C., Wolfson, J. S., McHugh, G. L., SWartz, M. D. TUNG, C. \& SWARTZ, M. N. (1984). Elimination of plasmid pMG110 from Escherichia coli by novobiocin and other inhibitors of DNA gyrase. Antimicrobial Agents and Chemotherapy 25, 586-590.

Howard-Flanders, P. \& Theriot, L. (1966). Mutants of Escherichia coli defective in DNA repair and in genetic recombination. Genetics 53, 1137-1150.

Howe, W. E. \& Mount, D. W. (1975). Production of cells without deoxyribonucleic acid during thymidine starvation of lex $A^{-}$cultures of Escherichia coli K12. Journal of Bacteriology 124, 1113-1121.

INOUYE, M. (1971). Pleiotropic effect of the recA gene of Escherichia coli: uncoupling of cell division from deoxyribonucleic acid replication. Journal of Bacteriology 106, 539-542.

JACOB, F., BRENNER, S. \& CUZIN, F. (1963). On the regulation of DNA replication in bacteria. Cold Spring Harbor Symposia on Quantitative Biology 28, 329-348.

JAFFÉ, A., D'ARI, R. \& HIRAGA, S. (1988). Minicell-forming mutants of Escherichia coli: production of minicells and anucleate rods. Journal of Bacteriology 170, 3094-3101.

JAFFE, A., OGURA, T. \& HiraGa, S. (1985). Effects of the $c c d$ function of the F plasmid on bacterial growth. Journal of Bacteriology 163 , 841-849.

JoHnson, B. F. (1977). Fine structure mapping and properties of mutations suppressing the lon mutation in Escherichia coli $\mathrm{K}-12$ and B strains. Genetical Research 30, 273-286.

KASs, L. R. \& YARMOLINSKY, M. B. (1970). Segregation of functional sex factor into minicells. Proceedings of the National Academy of Sciences of the United States of America 66, 815-822.

KLINE, B. C. \& MilleR, J. R. (1975). Detection of nonintegrated plasmid deoxyribonucleic acid in the folded chromosome of Escherichia coli: physiochemical approach to studying the unit of segregation. Journal of Bacteriology 121, 164-172.

KREUZER, K. N. \& CozZARELLI, N. R. (1979). Escherichia coli mutants thermosensitive for deoxyribonucleic acid gyrase subunit A: effects on deoxyribonucleic acid replication, transcription, and bacteriophage growth. Journal of Bacteriology 140, 424-435.

LEVY, S. B. (1970). Resistance of minicells to penicillin lysis: a method of obtaining large quantities of purified minicells. Journal of Bacteriology 103, 836-839.

Matsuzawa, H., Hayakawa, K., Sato, T. \& Imahori, K. (1973). Characterization and genetic analysis of a mutant of Escherichia col K-12 with rounded morphology. Journal of Bacteriology 115, 436442.

Menzel, R. \& Gellert, M. (1983). Regulation of the genes for E. coli DNA gyrase: homeostatic control of DNA supercoiling. Cell 34, 105-113.
Michel-Briand, Y., Uccelli, V., LAPORT, J. M. \& Plesiat, P. (1986). Elimination of plasmids from Enterobacteriaceae by 4-quinolone derivatives. Journal of Antimicrobial Chemotherapy 18, 667-674.

Miller, J. H. (1972). Experiments in Molecular Genetics, pp. 201-205. Cold Spring Harbor, NY: Cold Spring Harbor Laboratory.

Mount, D. W., Walker, A. C. \& Kosel, C. (1975). Effect of tsl mutations in decreasing radiation sensitivity of a $\mathrm{recA}^{-}$strain of Escherichia coli K-12. Journal of Bacteriology 121, 1203-1207.

Mulder, E. \& Woldringh, C. L. (1989). Actively replicating nucleoids influence positioning of division sites in Escherichia coli filaments forming cells lacking DNA. Journal of Bacteriology 171, 4303-4314.

Mulder, E., El'Bouhali, M., Pas, E. \& Woldringh, C. L. (1990). The Escherichia coli minB mutation resembles gyrB in defective nucleoid segregation and decreased negative supercoil of plasmids. Molecular and General Genetics 221, 87-93.

Nishimura, Y., Caro, L., Berg, C. M. \& Hirota, Y. (1971). Chromosome replication in Escherichia coli, IV. Control of chromosome replication and cell division by an integrated episome. Journal of Molecular Biology 55, 441-456.

Novick, R., Sanchez-Riva, C., Gruss, A. \& Edelman, I. (1980) Involvement of the cell envelope in plasmid maintenance: plasmid curing during the regeneration of protoplast. Plasmid 3, 348-358.

OGURA, T. \& HiRAGA, S. (1983). Mini-F plasmid genes that couple host cell division to plasmid proliferation. Proceedings of the National Academy of Sciences of the United States of America 80, 4784-4788.

OrR, E., Fairweather, N. F., Holland, I. B. \& Pritchard, R. H. (1979). Isolation and characterisation of a strain carrying a conditional lethal mutation in the cou gene of Escherichia coli K12. Molecular and General Genetics 177, 103-112.

Rashtchian, A., Brown, S. W., ReichleR, J. \& LeVy, S. B. (1986). Plasmid segregation into minicells is associated with membrane attachment and independent of plasmid replication. Journal of Bacteriology 165, 82-87.

Satta, G. \& PARdeE, A. B. (1978). Inhibition of Escherichia coli division by protein X. Journal of Bacteriology 133, 1492-1500.

ScoTt, J. R. (1984). Regulation of plasmid replication. Microbiological Reviews 48, 1-23.

SimoN, R. (1984). High frequency mobilisation of gram-negative bacteria replicons by the in vitro-constructed Tn5-Mob transposon. Molecular and General Genetics 196, 413-420.

SPRATT, B. G., BoYD, A. \& StOKER, N. (1980). Defective and plaqueforming lambda transducing bacteriophage carrying penicillinbinding protein-cell shape genes: genetic and physical mapping and identification of gene products from the lip-dacA-rodA-pbp-leuS region of the Escherichia coli chromosome. Journal of Bacteriology 143, 569-581.

Stanisich, W. A. (1988). Identification and analysis of plasmids at the genetic level. Methods in Microbiology 21, 11-47

Timmis, F., CABello, F. \& CoHEN, S. N. (1975). Cloning, isolation, and characterization of replication region of complex plasmid genomes. Proceedings of the National Academy of Sciences of the United States of America 72, 2242-2246.

WECHSLER, J. \& KLINE, B. C. (1980). Mutation and identification of the F plasmid locus determining resistance to acridine-orange curing. Plasmid 4, 276-280.

WEISSER, J. \& WIEDEMANN, B. (1985). Elimination of plasmids by new 4-quinolones. Antimicrobial Agents and Chemotherapy 28, 700-702.

WilletTS, N. (1988). Conjugation. Methods in Microbiology 21, 49-77.

Williams, D. R. \& Thomas, C. M. (1992). Active partitioning of bacterial plasmids. Journal of General Microbiology 138, 1-16.

Wolfson, J. S., Hooper, D. C., Swartz, M. N. \& McHugh, G. L. (1982). Antagonism of the B subunit of DNA gyrase eliminates plasmids pBR322 and pMG110 from Escherichia coli. Journal of Bacteriology 152, 338-344. 